\title{
DIFFERENT MANIFESTATIONS OF THELOHANELLUS NIKOLSKII INFECTION IN CARP (CYPRINUS CARPIO)
}

\author{
ĆIRKOVIĆ $M^{*}$, NOVAKOV NIKOLINA**, ALEKSIĆ NEVENKA***, JOVANOVIĆ ${ }^{* * * *}$, LJUBOJEVIĆ \\ DRAGANA*, BABIĆ $\mathrm{R}^{* * * *}$ and RADOSAVLJEVIĆ $\mathrm{V}^{* * * * *}$ \\ ${ }^{*}$ Scientific veterinary institute Novi Sad, Serbia \\ ${ }^{* *}$ University of Novi Sad, Faculty of Agriculture, Department of veterinary medicine, Serbia \\ *** University of Belgrade, Faculty of veterinary medicine, Serbia \\ ${ }^{* * * \star V e t e r i n a r y ~ i n s t i t u t e ~ o f ~ t h e ~ R e p u b l i c ~ o f ~ S r p s k a ~ „ D r ~ V a s o ~ B u t o z a n “, ~ R e p u b l i c ~ o f ~ S r p s k a, ~}$ \\ Bosnia and Hercegovina \\ ${ }^{\star * * * \star S c i e n t i f i c ~ V e t e r i n a r y ~ I n s t i t u t e ~ o f ~ S e r b i a, ~ B e l g r a d e, ~ S e r b i a ~}$
}

(Received 25 $5^{\text {th }}$ May 2013)

Thelohanellosis is a disease that occurs in all carp categories. The cause is protozoa Thelohanellus nikolskii Achmerov, 1955. It manifests itself in two forms. The first form occurs on the fins in oneyear-old carp fry and the second one occurs on scales in two-yearold, three-year-old and older categories of common carp (Cyprinus carpio). The researches conducted between 2008 and 2012 covered 22 fish ponds, 18 of which are located in Serbia, and 4 in Bosnia and Herzegovina, Republic of Srpska. It has been concluded that both forms of the disease were present in all observed fish ponds. Prevalence of telohanellosis located on the fins ranged between $3 \%$ and $30 \%$, and the infection intensity was between 2 and 86 cysts per individual, while in the case of thelohanellosis on scales the values were higher. Changes on the scales were present during April and May, and on the fins during July and August. After determination of morphological characteristics of spores and histopathological characteristics of plasmodia located on the fins and scales, no significant differences were noticed between them. Also, artificial infestation of carp fingerlings for species differentiation was done.

Since there are no adequate therapeutic measures, control of thelohanellosis is still based on compliance with basic sanitaryprophylactic measures such as drying of equipment, freezing, mechanical cleaning and disinfection with lime.

Key words: carp, fins, plasmodia, scales, Thelohanellus nikolskii 


\section{INTRODUCTION}

Achmerov (1955) described several species of myxosporean parasites including Thelohanellus nikolskii isolated from cysts presented on the fins. The same parasite was described by Hoshina and Hosoda (1957) in carp fingerlings in fish ponds in Japan and named it Thelohanellus cyprini. Ivasik and Karpenko (1967) reported that Thelohanellus nikolskii entered from the western parts of Ukraine to Belarus by means of wild carp, The same authors reported that wild carp and their hybrids transmitted the parasite via the river Amur to the Trans Siberian area (in 1963). Thelohanellus nikolskii infection in Europe was first reported in Hungary by Janey (1979) as cysts found on the fins of carp fingerlings. The parasite was introduced from the far East and causes each year an intensive infection of carp fry in Hungary (Molnar and Kovacs-Gayer, 1981-1982; Molnar, 2002). In Serbia Thelohanellus nikolskii was reported in the beginning of the eighties (Ćirković et al., 1983) and is still present. In Moldova, $T$. nikolskii infection was first recorded by Trombitsky et al. (1983, 1990). The first cases of thelohanellosis in Poland was described by Antychowicz (2003) and Kramer and Przybysz (2004). In Czech Republic, Novotny and Smolova (2006) was first who reported Telohanellus nikolskii infection of carp fingerlings which were imported in this country.

Wolf and Markiw (1984) were the first who described the life cycle of Myxobolus cerebralis, while Yokoyama (1997) and Székely et al. (1998) finally described the life cycle of Thelohanellus nikolskii and Thelohanellus hovorkai. Intermediate hosts are oligochaetes, usually Tubifex tubifex in which actinosporean stages transform into the aurantiactinomyxson spores which are infective to fish. Pathological changes caused by $T$. nikolskii infection on the fins were studied by Molnar (1982), Ćirković (1986) and Ćirković et al. (1997). Changes on the fins are characterized by the appearance of plasmodia 1-2 mm size (Molnar, 1982; Ćirkovic, 1986) in one-year-old carp. Ćirković et al. (1997) presented the six thelohanellosis phases that occur in carp fingerlings aged 21 to 70 days.

Desser et al. (1983) described the ultrastructural characteristics of sporogenesis of T. nikolskii from the fins.

The host immune response to the presence of these parasites occurs through cellular immunity, and tissue reaction. Studies showed that the humoral response to myxsosporeans is quite low (Griffin and Davis, 1979). Myxsosporeans probably avoid the creation of antibodies by the host hiding antigen (Pauley 1974; McArthur and Sengupta 1982). Diagnosis of the disease is based on clinical findings, presence of spores with characteristic morphology and size specific for each Thelohanellus species, and pathohistological structure of plasmodia. Also, a very reliable method of diagnostics is the molecular characterization of spores especially for the determination of new or similar species.

Moshu and Molnar (1997) described for the first time Thelohanellus infection of scales in 2-4 years old European wild carp (Cyprinus carpio carpio) collected 
from water reservoirs of Moldova. Ćirković et al. (2009), Milošević (2009) and Novakov (2013) have detected and described Thelohanellus nikolskii infection of the scales in common carp (Cyprinus carpio) from Serbian fish farms. Changes are visible in the form of cysts on the scales reaching up to $3 \mathrm{~mm}$ in diameter.

The goal of this paper is to present and compare two different forms and clinical manifestations of diseases caused by Telohanellus nikolskii.

\section{MATERIAL AND METHODS}

The investigation was conducted from 2008 to 2012 on 18 fish farms in Serbia (Bač, Svilojevo, Kolut, Sombor, Srpski Miletić, Ruski Krstur, Susek, Despotovo, Bečej, Žabalj, Lukino Selo, Mošorin, Sečanj, Banatski Dvor, Novi Itebej, Jazovo, Novi Kneževac, Kanjiža) and 4 fish farms in Bosnia and Hercegovina, Rebublic of Srpska (Prijedor, Prnjavor, Bardača, Brod). Fish farms were chosen taking into account to cover the area of supply of all rivers that are recipient of most carp ponds in Serbia.

The subject of the investigation was 1 to 4 year-old pond-cultured common carp (Cyprinus carpio). Sampling was conducted between April and October with intervals of 7-14 days. During each visit to the pond, clinical examinations was conducted on hundreds of fish. For laboratory examination, complete parasitological dissection was performed on 21 specimens of common carp. Fish were transported to the laboratory in plastic bags with water and oxygen. Clinical changes of the carps were photographed in the laboratory.

Light microscopy examinations of fresh smears from different organs were conducted during dissection by compression between 2 slides. The location of the cysts was recorded. Measuring of fresh spores and capsule length and width was performed by using software program Cell $B$.

Pathohistological examination was conducted by standard techniques: following fixation of the tissue samples, sliced to $5-\mu m$-thick sections, mounted and stained in haematoxylin and eosine. Micrographs were taken with Olympus BX51 microscope, using Color View III digital camera.

Artificial infestation of carp fingerlings for purposes of species differentiation and clinical monitoring was done in a fish pond in Mošorin which was only a few years old and uses well water free of parasites and intermediate hosts.

The influence of certain technological processes such as drying, freezing, mechanical processing of soil and disinfection with lime on the occurrence of thelohanellosis was monitored, also.

\section{RESULTS}

Thelohanellosis was diagnosed in all 22 investigated fish farms. The form of the disease which occurs on the fins was present in 60 days old carp fingerlings. Cysts present on fins were round and 1-2 $\mathrm{mm}$ in diameter. The prevalence of 
infection ranged from $3-30 \%$, and the intensity was 2 to 84 cysts per fish (Table 1). The disease was most intensely manifested in late July through August, while during the rest of the growing season was recorded sporadically. During the whole season malformations and defects of the fins were detected in carp fingerlings. Individuals who had a loss of tail fin substance became the prey of fish eating birds. Cysts were present in all fins (Figure 1). The majority of cysts were present on the tail fin, then on the dorsal, pectoral, abdomonal and anal fins (Figures 1, 2).

Cysts on fins in two-year old carp fingerlings were present sporadically in few fish throughout the whole investigation, while in tree-year old carps and older categories cysts were not observed at all.

In 2008, the cysts were recorded on scales in Susek, Žabalj, Jazovo and Bač fish ponds, while in the period 2009-2012 changes on the scales were present in all investigated farms. Plasmodia on the scales were present from the beginning of April until the end of May, while characteristic scale changes were not observed during the rest of the year. The prevalence of infection ranged from 2 to $75 \%$,

Table 1. Prevalence and intensity of infection of fins on investigated fish farms

\begin{tabular}{|l|c|c|}
\hline Fish farm & Prevalence (\%) & $\begin{array}{c}\text { Intensity (number of cysts } \\
\text { per fish) }\end{array}$ \\
\hline Bač & 6 & $10-55$ \\
\hline Svilojevo & 8 & $20-60$ \\
\hline Kolut & 4 & $7-23$ \\
\hline Sombor & 5 & $24-48$ \\
\hline Srpski Miletić & 15 & $6-51$ \\
\hline Ruski Krstur & 5 & $4-32$ \\
\hline Susek & 30 & $20-84$ \\
\hline Despotovo & 14 & $15-61$ \\
\hline Bečej & 6 & $12-38$ \\
\hline Žabalj & 25 & $10-64$ \\
\hline Lukino Selo & 10 & $6-61$ \\
\hline Mošorin & 8 & $2-36$ \\
\hline Sečanj & 5 & $4-28$ \\
\hline Banatski Dvor & 7 & $2-56$ \\
\hline Novi Itebej & 25 & $10-65$ \\
\hline Jazvo & 20 & $10-70$ \\
\hline Novi Kneževac & 6 & $6-28$ \\
\hline Kanjiža & 7 & $5-54$ \\
\hline Prijedor & 4 & $3-37$ \\
\hline Prnjavor & 6 & $4-35$ \\
\hline Bardača & 8 & $5-48$ \\
\hline Brod & 3 & $2-43$ \\
\hline
\end{tabular}


Table 2. The results of measurements of spores isolated from fins and scales.

\begin{tabular}{|c|c|c|c|c|}
\hline $\begin{array}{c}\text { Localization of } \\
\text { spores }\end{array}$ & $\begin{array}{c}\text { Spore lenght } \\
(\mu \mathrm{m})\end{array}$ & $\begin{array}{c}\text { Spore width } \\
(\mu \mathrm{m})\end{array}$ & $\begin{array}{c}\text { Capsule lenght } \\
(\mu \mathrm{m})\end{array}$ & $\begin{array}{c}\text { Capsule width } \\
(\mu \mathrm{m})\end{array}$ \\
\hline Scales & $\begin{array}{c}17.7 \\
(13.5-20.3)\end{array}$ & $\begin{array}{c}10.9 \\
(10-12.1)\end{array}$ & $\begin{array}{c}7.1 \\
(6.1-8.7)\end{array}$ & $\begin{array}{c}6.2 \\
(5,8.6,6)\end{array}$ \\
\hline Fins & $\begin{array}{c}17.2 \\
(13.4-20.6)\end{array}$ & $\begin{array}{c}10.8 \\
(9.2-13.3)\end{array}$ & $\begin{array}{c}6.5 \\
(5.8-7.6)\end{array}$ & $\begin{array}{c}5.9 \\
(5.2-6.8)\end{array}$ \\
\hline
\end{tabular}

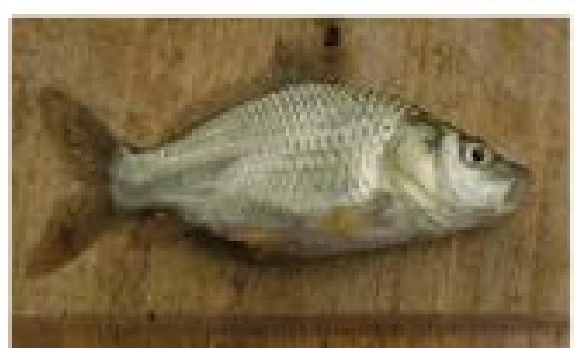

Figure 1. Cysts present on all fins of one-year old common carp.

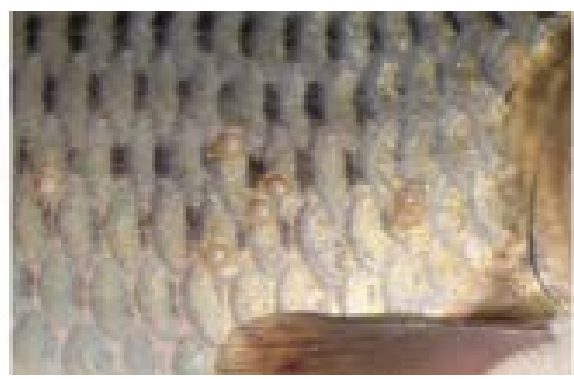

Figure 3. The appearance of cysts present on scales of two-year old carp fingerlings.

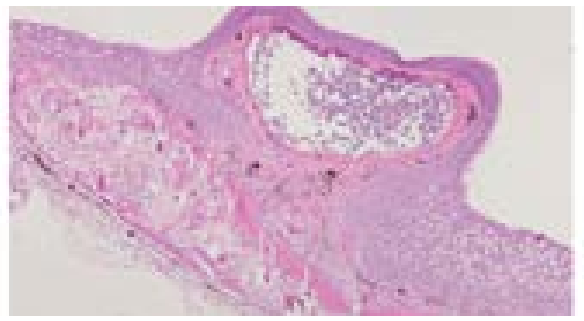

Figure 5. Cross section of scale with present plasmodium of one-year old carp. H\&E, x200

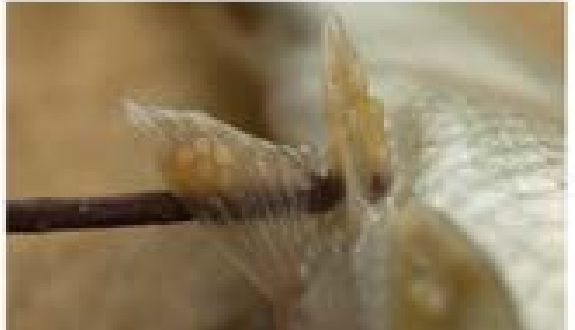

Figure 2. Mature cysts on pectoral fins of one-year old carp fingerling.

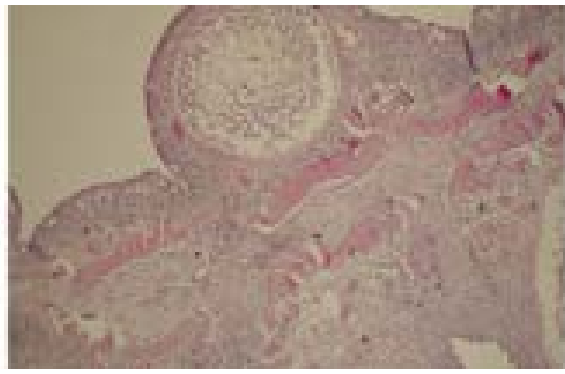

Figure 4. Cross section of one-year old carp finrays with present plasmodium. H\&E, x200

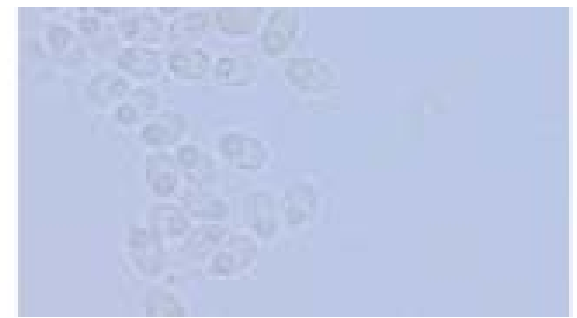

Figure 6. Spores isolated from plasmodia of fins. 


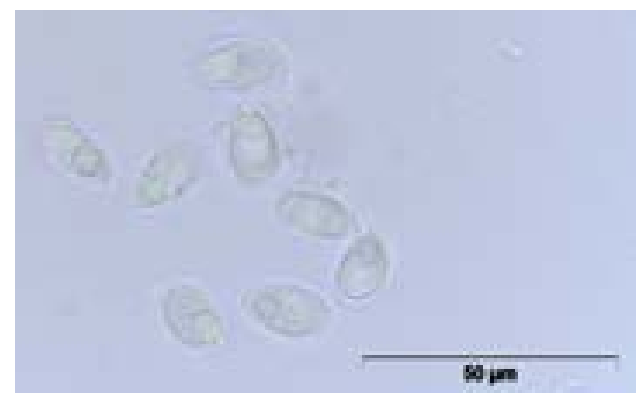

Figure 7. Spores isolated from plasmodia present on scales.

while its intensity was 2 -206 cysts per fish. Cyst were round and 1-3 $\mathrm{mm}$ in size and located on the outher margins of the scales (Figure 3). The form of the disease present on the scales was described in two-year-old fingerlings that were the most often infected, but also sporadically in three-year and four-year old common carps. Also sporadically, cysts were detected on the skin of four-year-old spawn carp. Cysts were not observed in one-year-old fry at all.

Artificial infestation of carp fingerlings was done in a fish pond in Mošorin. After entering a few individuals who had cysts on the scales, during the next vegetation period there were two forms of the disease, separately and at different times.

Histological structure of the fins is similar to the structure of the scales. The fin rays are built up from calcified collagen. The structure of the scales inside the dermis also consists of plates of calcified collagen. Cells surrounding the calcified collagen excrete collagen to the outer surface. Externally the dermis is covered by multilayered epidermis overlying a membrana basialis. The epithelium is rich in goblet cells which can be seen on histological sections.

After pathohistological examination it can be seen that in both forms of the disease the structure is almost the same (Figures 4, 5). Plasmodia on the fins and scales develops on fin rays and scale surface inside a calcified collagenic capsule (Figures 4, 5). Cartilaginous parts around the plasmodia break into pieces and calcified islets appear inside the connective tissue around the cyst (Figures 4, 5). The wall of the cysts around the plasmodium contain elongated cyst-forming cells. The central parts of plasmodia are filled with spores, while in the periphery vegetative developmental stages and pansporoblasts are present (Figures 4, 5). Deposits of melanin can be seen around the plasmodia. It is a special and unusual phenomenon of tissue reaction. Great plasmodia can be colored to black due to melanin or contain extracellular or intracellular deposits of melanocytes (Dycova, 1984).

For determination or description are using fresh spores, in exceptional cases spores fixed in $10 \%$ formalin can be used.The determination of the spores was done using light microscopy according to the methods determined by Shulman 
(1984) and Lom and Arthur (1988). The shape and size of the spores are very important for the final determination.

Fresh spores were isolated from plasmodia of fins and scales and were compared to each other. In both cases isolated spores were oval, with one large polar capsule and sporoplasm (Figures 6,7 ). Measurement values of fresh spores and polar capsules lenght and width are shown in Table 2.

\section{DISCUSSION}

The shape and size of Thelohaellus nikolskii spores from the plasmodia on the fins correspond to spores from scales, only the spores and polar capsules from the scales are slightly longer and wider. The shape and size of spores from fins and scales, also correspond to measurements of spores from fins given by Molnar (1982), Trombitsky et al. (1983), Ćirković (1986) and Dycova and Lom (1988).

By analyzing the patohystological structure of the plasmodia from the fins and scales an almost identical structure, as described by Moshu and Molnar (1997) can be seen. By molecular characterisation of the parasite from the scales was confirmed that the etiological cause was Thelohanellus nikolskii Achmerov, 1955 is the same for both forms of the disease which occurs on the scales and on the fins (Novakov, 2013).

Also, results of artificial infestation indicate the presence of the same agent, but in two different clinical forms of the disease.

In one year-old carp fingerlings the location of the cysts are the fin rays, while in two years old and older carps the cysts are located on the scales. According to Moshu and Molnar (1997) in older fish due to advanced calcification of fin rays the cartilage is less suitable for plasmodium formation than are the scales.

The changes on the scales occur in April and May, and on the fins during July and August. Considering that, cysts on the fins which are present only in one-year old carp fingerlings can not mature before, rather is in the timing of the scales changes developement, because in Serbia larvae are stocked during May and a certain amount of time is required in order to become visible.

Literature data reported by Janey (1979), Janey and Molnar (1981), Molnar and Kovach-Gayer (1981-1982), Molnar (1982), Ćirković (1986) and Ćirković et al. (1997), concluded that the prevalence and intensity of thelohanellosis on the fins is smaller than in the period of the mid-eighties. It is possible that this was affected by the application of freezing and drying of fish pond facilities for growing a fingerlings, as well as changes in technology which have occoured at the time. The prevalence and intensity of infection were most on fish farms where facilities for breeding are not strictly defined, and were rarely dried, frozen and mechanically cleaned, thus allowing intermediate hosts to be present during the next growing season. Also, the prevalence and intensity of infection were higher in facilities where stocking densities were higher, and therefore immunity and conditions of fish were weaker. Wasteing due to thelohanellosis on the fins can be significant 
due to loss of the fins. When the desease is present on the scales losses are not direct as after the cysts fall off only lesions and discolorations are evident.

The significant moment for thelohanellosis spreading is movement of fry between fish ponds where this disease was not taken into account. The second important factor is hydrographical connection between fish ponds, where water circulation enables transmission. Given the fact that the distance between fish ponds is small, fish eating birds are also an important factor in disease spreading.

During the experiment for the prevention and treatment of myxosporean Ćirković (1986) found that only nitrofuran drugs are effective in the treatment of sphaerosporidiosis but not in the case of thelohanellosis. It was reported that the only efficacious chemotherapeutic drug against myxosporean diseases is fumagilin (Hedrick et al.,1988; Székely et al., 1988; Wishovsky et al., 1990; Yokoyama et al., 1990; El-Matbouli and Hoffmann 1991; Sitja-Bobadilla and Alvarez-Pellitero 1992; Rhee et al., 1993; Yokoyama et al., 1999). However, fumagilin could not be used for the treatment of myxosporean diseases due to unresolved problem with toxic residues in tissues and the withdrawal time of the drug. So the control of thelohanellosis is still based on compliance with basic sanitary-prophylactic measures such as drying of objects, freezing, mechanical cleaning and disinfection with lime.

Address for correspodence:

Dr Miroslav Ćirković

Scientific veterinary institute Novi Sad

Rumenački put 20

21000 Novi Sad, Serbia

E-mail: miroslavcirkovic@yahoo.com

\section{REFERENCES}

1. Achmerov AC, 1955, Ways of the origin of Myxosporidia species of the genus Thelohanellus Kudo from Amur wild carp, Dokl Akad Nauk SSSR, 105, 1129-32 (in Russian).

2. Antychowicz J, 2003, Carp diseases in Poland caused by Myxosporea parasite (Buetschli 1881), Medycyna Wet, 59, 762-6.

3. Ćirković M, 1986, Myxosporidiosis of the common carpfingerlings, PhD thesis, Veterinary faculty, Belgrade, (in Serbian).

4. Ćirković M, Ćirković D, Lubat V, 1997, Characteristic developmental stages of Thelochanellus nikolskii (1979-1996), Acta Vet (Belgrade), 47, 4, 221-35.

5. Ćirković M, Milošević N, Jovanović M, Jeremić S, Radosavljević V, 2009, Thelohanellosis of the scales in the two-year-old cultured common carp (Cyprinus carpio), $14^{\text {th }}$ EAFP International Conference, Prague, Book of abstracts, 251.

6. Ćirković M, Petrović Z, Jovanović B. 1983. Thelohanellus of carp in the teritory of Yugoslavia. - Ist International symposium of ichtyoparasitology parasites and parasitic diseases of fish, Č. Budejovice, Book of abstracts, 38.

7. Desser SS, Molnar K, Weller I, 1983, Ultrastructure of sporogenesis of Thelohanellus nikolskii Achmerov, 1955 (Myxozoa: Myxosporea) from the common carp, Cyprinus carpio, J Parasitol, 69504-518. 
8. Dycova I, 1984, The role of melanomacrofage centres in the tissue reaction to myxosporean infections of fishies, Bull Eur Ass Fish Pathol, 4, 65-67.

9. Dycova I, Lom J, 1988, Review of pathogenic myxosporeans in intensive culture of carp (Cyprinus carpio) in Europe, Folia Parasitol, 36, 289-307.

10. El-Matbouli M, and Hoffmann RW, 1991, Prevention of experimentally induced whirling disease in rainbow trout Oncorhynchus mykiss by fumagillin, Diseases of Aquatic Organisms, 10, $109-13$.

11. Griffin B, Davis E, 1978, Myxosoma cerebralis : Detection of circulating antibodies in infected rainbow throut, J Fish Res Board Can, 35, 1186-90.

12. Hedrick RP, Groff JM, Foley P, McDowell $T$, 1988, Oral admimistration of fumagillin DCH protects chinook salmon Oncorhynchus tshawytscha from experimentally-induced proliferative kidney disease, Dis of Aquat Org, 4, 165-8.

13. Hosina T, Hosoda S, 1957, On a new Myxosporidian species, Thelohanellus cyprini n. sp., parasitic in the fin of Cyprinus carpio, $J$ Tokyo Univ Fish, 43, 71-3.

14. Ivasik M, Karpenko M, 1967, The cange of parasite fauna of Cyprinus carpio haemotopterus Tem. Rt. Schl. At. Its. Introduction in fish ponds of the Ukraine (in Russian), Parazitologija, 1, 149-50.

15. Janey G, 1979, The occurrence of Thelohanellus dogieli Achmerov 1955 (Myxosporidia) on carp (Cyprinus carpio) in fish ponds in Hungary, Parasitol Hung, 12, 19-2.

16. Janey G, Molnar K, 1981, Thelohanellosis of the common carp in Hungary In: Fish, pathogens and environment In European polyculture, Proceedings of an International Seminar, Haltenyesztisi Kutato Intezet, Szarvas, 205-9,

17. Kramer I, Przybysz M, 2004, Myxobolosis and Telohanellosis - fish diseases caused by Myxosporea, Przegląd Rybacki, 1, 22-7.

18. Lom J, Arthur JR, 1988, A guideline for the preparation of species description In Myxosporea, J Fish Dis, 12: 151-156.

19. Mcarthur $C P$, Sengupta, 1982, Antigen mimicry of eel tissue by a mixosporidian parasite, $Z$ Parasitenkd, 66, 249-55.

20. Milošević N, 2009, Thelohanellosis of one-year old and two-year old carp fingerlings, Magistral thesis, University of Novi Sad, (in Serbian).

21. Molnar K, 1982, Biology and histopathology of Thelohanellus nikolskii Achmerov, 1955 (Myxosporea, Myxozoa), a protozoan parasite of the common carp (Cyprinus carpio), Z Parasitenkd, 68, 269-77.

22. Molnar K, 2002, Differences between the European carp (Cyprinus carpio carpio) and the colored carp (Cyprinus carpio haematopterus) in susceptibility to Thelohanellus nikolskii (Myxosporea) infection, Acta Vet Hung , 50, 51-7.

23. Molnar K, Kovacs-Gayer, 1981-1982, Occurrence of two species of Thelohanellus (Myxosporea: Myxozoa) of Far-East origin in common carp populations of the Hungarian fish farms, Parasit Hung, 14, 51-5.

24. Moshu A, Molnar K, 1997, Thelohanellus (Myxozoa: Myxosporea) infection of the scales in the European wild carp Cyprinus carpio carpio, Dis Aquat Org, 28, 115-23.

25. Novakov N, 2013, Fish diseases caused by species Thelohanellus nikolskii, University of Novi Sad, Doctoral thesis, (in Serbian).

26. Novotny L, Smolova J, 2006, Thelohanellus nikolskii in imported fingerlings of common carp (Cyprinus carpio) in the Czech Republic - a case report, Bull Eur Ass Fish Pathol, 26, 3, 128.

27. Pauley G, 1974, Fish sporozoa: Ekstractions of antigens from Myxosoma cerebralis which mimic tissue antigensof rainbow throut, J Fish Res Board Can, 3,1481-4.

28. Rhee JK, Kim HC, Park BK, 1993, Efficacy of fumagillin against Thelohanellus kitauei infection of Israel carp, Cyprinus carpio nudus, Kor J Parasitoly, 31, 57-65.

29. Shulman SS, 1984, [Parasitic Protozoa.] Vol.1. In: O.N. Bauer (Ed.), [Key to the Parasites of Freshwater Fauna of SSR, Vol. 140 of the Keys to the Fauna of the USSR. Nauka, Leningrad, 428 pp. (In Russian). 
30. Sitja-Bobadilla, Alvarez-Pellitero $P, 1992$, Effect of fumagillin treatment of see bass Dicentrarchus labrax parasitized by Sphaerospora testicularis (Myxosporea: Myxozoa) in oligochaete alternate host, Dis Aquat Org, 14, 171-8.

31. Székely C, El-Mansy A, Molnár K, Baska F, 1998, Development of Thelohanellus hovorkai and Thelohanellus nikolskii (Myxosporea: Myxozoa) in oligochaete alternate hosts, Fish Pathol, 33, 107-114.

32. Székely C, Molnar K, Baska F, 1988, Efficacy of fumagillin against Myxidium giyrdi Cepede, 1906 Infection of the European eel (Anguilla anguilla): new observation on myxodiosis of imported glass eels, Acta Vet Hungarica, 36, 239-46.

33. Trombitsky ID,, Golovina N.A., Sheinin ME, 1983, Thelohanellosis of common carp, Ei Cniiiteirh 8:12-15 (in Russan),

34. Trombitsky ID, ShelnIn ME, Hlanla VM, 1990, Biology and pathogenicity of Thelohanellus nikolskii, Parazitologiya, 24,354-358 (in Russian).

35. Wishovsky A, Groff JM, Lauren DJ, Toth RJ, Hedrich RP, 1990, Efficacy of fumagillin against proliferative kidnay disease and its toxic side effects in rainbow trout (Oncorhynchus mykiss) fingerlings, Fish Pathology 25, 141-146.

36. Wolf K, Markiw ME, 1984, Boilogy contravenes taxonomy in the Myxozoa: new discoveries show alternation of invertebrate and vertebrate hosts, Science, 225, 1449-52.

37. Yokoyama H, 1997, Transmission of Thelohanellus hovorkai Achmerov, 1960 (Myxosporea: Myxozoa) to common carp, Cyprinus carpio, through the alternate oligochaete host, Syst Parasitol, 36, 79-84.

38. Yokoyama $H$, Liyanage YS, Sugai A, Wakabayashi $H$, 1999, Efficacy of fumagillin against haemorrhagic thelohanellosis caused by Thelohanellus hovorkai (Myxosporea: Myxozoa) in coloured carp, Cyprinus carpio L, J Fish Dis, 22, 243-5.

39. Yokoyama $H$, Ogawa $K$, Wakabayashi $H$, 1990, Chemotherapy with fumagillin and toltrazuril against kidney enlargaments disease of goldfish coused by the myxosporean Hoferellus carassi, Fish Pathology, 25, 157-63.

\section{RAZLIČITE MANIFESTACIJE OBOLENJA IZAZVANOG THELOHANELLUS NIKOLSKII KOD ŠARANA (CYPRINUS CARPIO)}

\section{ĆIRKOVIĆ M, NOVAKOV NIKOLINA, ALEKSIĆ NEVENKA, JOVANOVIĆ M, LJUBOJEVIĆ DRAGANA, RADOSAVLJEVIĆ V. i BABIĆ R}

\section{SADRŽAJ}

Telohaneloza je obolenje koje se javlja kod svih kategorija šarana. Uzročnik je protozoa Thelohanellus nikolskii Achmerov, 1955. Manifestuje se u dva oblika. Prvi se javlja kao telohaneloza na perajima kod jednogodišnjih mladunaca šarana a drugi kao telohaneloza krljušti kod dvogodišnjih, trogodišnjih i višegodišnjih kategorija ribnjačkog šarana (Cyprinus carpio). Istraživanjima koja su trajala u periodu od 2008.-2012. godine obuhvaćeno je 22 ribnjaka od čega se 18 nalaze u Srbiji a 4 u BIH, Republika Srpska. Utvrđeno je da su oba oblika obolenja bila prisutna na svim ispitivanim ribnjacima. Kod telohaneloze na perajima, prevalenca se kretala od 3-30\% a intenzitet infekcije od 2-84 cisti po jedinki, dok su te vrednosti kod telohaneloze na krljištima bile veće. Promene na krljuštima bile su prisutne tokom aprila i maja a na perajima tokom jula i avgusta. 
Utvrđivanjem morfoloških karakteristika spora iz cisti sa peraja i krljušti, kao i prilikom determinacije patohistoloških karakteristika plazmodijuma nisu uočene značajne razlike između njih. Takođe je urađen i ogled veštačkog zaražavanja mladunaca šarana radi diferencijacije vrste.

Pošto ne postoji ni jedno adekvatno terapeutsko sredstvo kontrola telohaneloze i dalje se bazira na pridržavanju osnovnih sanitarno profilaktičkih mera kao što su isušivanje objekata, izmrzavanje, mehanička obrada tla i dezinfekcija krečom. 